\title{
The contradictions of regionalism in North America
}

\author{
ANN CAPLING AND KIM RICHARD NOSSAL*
}

\begin{abstract}
Students of regionalism almost reflexively include North America in their lists of regions in contemporary global politics. Inevitably students of regionalism point to the integrative agreements between the countries of North America: the two free trade agreements that transformed the continental economy beginning in the late 1980s - the Canada-US Free Trade Agreement that came into force on 1 January 1989, and the North American Free Trade Agreement (NAFTA) between the United States, Mexico, and Canada, that came into force on 1 January 1994 - and the Secutity and Prosperity Partnership of North America (SPP), launched in March 2005. These agreements, it is implied, are just like the integrative agreements that forge the bonds of regionalism elsewhere in the world. We argue that this is a profound misreading, not only of the two free trade agreements of the late 1980s and early 1990 s and the SPP mechanism of 2005, but also of the political and economic implications of those agreements. While these integrative agreements have created considerable regionalisation in North America, there has been little of the regionalism evident in other parts of the world. We examine the contradictions of North America integration in order to explain why North Americans have been so open to regionalisation but so resistant to regionalism.
\end{abstract}

\section{Introduction}

Announcing his candidacy for the presidency in November 1979, Ronald Reagan articulated a vision for what he termed a 'North American Accord' between Canada, the United States and Mexico, promising that he would 'work toward the goal of using the assets of this continent ... for the common good of all its people'. $\mathrm{He}$ acknowledged that such a process 'may take the next 100 years',

but we can dare to dream that at some future date a map of the world might show the North American continent as one in which the people's commerce of its three strong countries flow more freely across their present borders than they do today. ${ }^{1}$

Although Reagan was prompted to abandon his idea as a result of negative reaction in both Canada and Mexico, in the end it did not take 100 years for 'the people's commerce' to flow more freely in North America. Within six years, Canada's

* We would like to thank the Australian Research Council and the Social Sciences and Humanities Research Council of Canada for making this research possible, and Michael Barkun, Stephen Clarkson, David Haglund, Andrew Hurrell, Laura Macdonald, Robert Pastor, the anonymous referees and the editor, Rick Fawn, for helpful suggestions and criticisms.

1 'Ronald Reagan's Announcement for Presidential Candidacy', New York, 13 November 1979, The Public Papers of President Ronald W. Reagan, Ronald Reagan Presidential Library: $\langle\mathrm{http}: / / \mathrm{www} . \mathrm{reagan}$.utexas.edu/archives/reference/11.13.79.html . 
prime minister, Brian Mulroney, would approach the US to launch negotiations for a free trade agreement; within a decade, the Canada-US Free Trade Agreement (CUSFTA) would be in force, Mulroney's Progressive Conservative party having fought the 1988 election mainly on the free trade issue. The CUSFTA provided a template for the initiation of free trade talks between Mexico and the US in June 1990, which were subsequently trilateralised to include Canada in February 1991. The North American Free Trade Agreement (NAFTA), designed to liberalise trade and investment flows, was signed in December 1992 and came into force on 1 January 1994 - just fourteen years after Reagan's speech.

NAFTA, bringing together two highly developed ind ustrialised economies and a developing country, had a transformative impact on the North American economy. In the decade after 1994, intraregional transactions grew by over 80 per cent; exports and imports between the NAFTA signatories nearly doubled; investment flows more than doubled; more than 20 million new jobs were created. ${ }^{2}$ To be sure, assessments of NAFTA's effects invariably point to the uneven nature of the economic benefits created, to the negative impacts of the agreement on some sectors and groups, and even to the contested causality of the economic changes observed. ${ }^{3}$ But most economists would probably agree with Clemente Ruiz Durán that, considered from a purely economic perspective, NAFTA was 'the most successful trade agreement in the global economy'. ${ }^{4}$ Certainly NAFTA deepened the continentalisation that had developed over the twentieth century between the US and its neighbours. As a Council of Foreign Relations report noted in 2005, NAFTA created a 'North American economic space' by making 'the outlines of a North American economy visible'. ${ }^{5}$

And yet North America presents students of regionalism with a puzzle. On the one hand, NAFTA has clearly fostered the intensification of regionalisation, the process of economic integration that is driven from the bottom up by private actors such as firms in response to the opportunities created by the liberalisation of investment and trade. On the other hand, NAFTA has not led to greater regionalism, that is, state-led efforts to deepen regional integration through the fostering of other formal mechanisms to support institutionalised cooperation and collective action. ${ }^{6}$ Even as state-led efforts to promote regionalism gathered momentum elsewhere-most notably in East Asia ${ }^{7}$ - North American regionalism has barely deepened since the implementation of NAFTA.

${ }^{2}$ Gary Clyde Hufbauer and Jeffrey J. Schott, NAFTA Revisited: Achievements and Challenges (Washington, DC: Institute for International Economics, 2005), p. 2, 69-72.

3 Clemente Ruiz Durán, 'NAFTA: Lessons from an Uneven Integration', International Journal of Political Economy, 33:3 (2003), pp. 50-71; Dominick Salvatore, 'Economic Effects of NAFTA on Mexico', Global Economy Journal, 7:1 (2007), article 1; Hufbauer and Schott, NAFTA Revisited, pp. 3-5.

4 Ruiz Durán, 'Uneven Integration', p. 53.

5 Building a North American Community, Independent Task Force Report 53 (Council on Foreign Relations, 2005), pp. 18, 20.

${ }^{6}$ On regionalisation and regionalism, Andrew Hurrell, 'Explaining the Resurgence of Regionalism in World Politics', Review of International Studies, 21:3 (1995), pp. 331-58; and Richard Higgott, 'De Facto and De Jure Regionalism: The Double Discourse of Regionalism in the Pacific', Global Society, 11:2 (1997), pp. 165-83.

${ }^{7}$ Richard Higgott and Richard Stubbs, 'Competing Conceptions of Economic Regionalism: APEC versus EAEC in the Asia Pacific', Review of International Political Economy, 2:3 (1995), pp. 549-68; and the contributions in T. J. Pempel (ed.), Remapping East Asia: The Construction of a Region (Ithaca, NY: Cornell University Press, 2004). 
This puts the North American case seriously at odds with neo-functionalist theories of regionalism. Popularised in the 1950s with the emergence of integration in western Europe, neo-functionalism argued that economic integration through regional trade agreements inevitably produces spill-over effects into other policy domains, and creates pressures for political integration more generally. ${ }^{8} \mathrm{Neo}-$ functionalism enjoyed a renaissance in the 1980s and 1990s, not just as a result of the establishment of the European Union with its supranational institutions, but also because of the appearance of new regional trade agreements in East Asia, Southern Africa, and in South and North America.

Apart from the EU project itself, NAFTA was considered to be the deepest and most integrative of these regional schemes. As Sidney Weintraub observed,

despite the words 'free trade' in its name, it is much more than a trade agreement. NAFTA is intended to encompass an array of economic relations beyond trade in goods and services, such as investment, transportation, communications, border relations, environmental and labor matters, just to name a few. Stated more provocatively, NAFTA has the potential to alter political relations among the three countries ...9

Indeed, given NAFTA's breadth of coverage, neo-functionalism would have predicted that the agreement would have generated spillovers into other areas such as monetary cooperation, the harmonisation of social policy, and, ultimately, political integration.

However, nothing of the sort has occurred. While NAFTA has been institutionalised, ${ }^{10}$ it has not developed deeper institutions of governance, ${ }^{11}$ and has not 'progressed' into deeper cooperative arrangements in other policy domains. ${ }^{12}$ Moreover, despite elite-driven efforts to deepen NAFTA and to construct notions of a regional community, a North American 'imaginary' has not emerged. Rather, the opposite has occurred: we have seen the 're-borderisation' of the US in the wake of the attacks of 11 September 2001, the deflection by governments of elite proposals for the deepening of NAFTA, and a resurgence of nationalism and parochialism that has precluded the growth of a North American 'community' or 'identity'.

Our purpose is to explore the contradictions of regionalism in North America and to explain why North Americans have been so open to regionalisation but so resistant to regionalism. First, we examine the dynamics which led to NAFTA, noting that in contrast to regional integration projects that were occurring elsewhere, NAFTA was not driven by a desire to strengthen regionalism per se. Rather, NAFTA originated

8 The early 'classics' include Ernst Haas, Beyond the Nation-State: Functionalism and International Organization (Stanford, CA: Stanford University Press, 1964); and Leon Lindberg, The Political

Dynamics of European Economic Integration (Stanford, CA: Stanford University Press, 1966).

${ }^{9}$ Sidney Weintraub, NAFTA: What Comes Next? (Westport, CT: Praeger, 1994), p. 2.

${ }^{10}$ Michael Lusztig and Patrick James, 'Institutionalizing NAFTA', Law and Business Review of the Americas, 11:3/4 (2005), pp. 551-73.

11 Jeffrey Ayres and Laura Macdonald, 'Deep Integration and Shallow Governance: The Limits to Civil Society Engagement Across North America', Policy and Society, 25:6 (2007), pp. 23-42.

12 Pace Stephen Clarkson, who sees such features as NAFTA's Chapter 11, which gives corporations rights to make claims against the three NAFTA governments in a trinational tribunal, as 'supraconstitutional'. Clarkson, 'Manoeuvring within the Continental Constitution: Autonomy and Capacity within the Security and Prosperity Partnership of North America', in Jean Daudelin and Daniel Schwanen (eds), Canada Among Nations 2007: What Room for Manoeuvre? (Montreal and Kingston: McGill-Queen's University Press, 2008), pp. 248-67. For a different perspective on NAFTA's Chapter 11, see Ann Capling and Kim Richard Nossal, 'Blowback: Investor-State Dispute Mechanisms in International Trade Agreements', Governance: An International Journal of Policy, Administration, and Institutions, 19 (2006), pp. 151-72. 
in what Robert Pastor has characterised as the 'dual-bilateralism'13 of North American international relations - that is, where the dominant patterns of interaction are on US-Canada and US-Mexico bilateral axes. Part two explores the aftermath of $9 / 11$, which disrupted the openness of American borders, and propelled business elites to advance proposals for the deeper economic integration. We argue that these proposals, which borrow from the European 'template' for regional integration, are premised on out-dated notions that see regionalism as economically determined rather than socially constructed. The third part explores governmental and civil society responses to these elite-driven proposals, demonstrating the degree to which elites have not been able to convince either government officials or civil society actors of their vision for a regional community. Finally, we examine the role of the US in North American regionalism and ask whether regionalism is possible when it would necessarily involve curbs on American autonomy and sovereignty. While this would seem an obvious question, surprisingly it is not one that has been widely canvassed in the literature on North American 'regionalism'. We conclude by noting that the contradictions of regionalism in North America render unlikely the prospects for the development of a North American community.

\section{NAFTA: from 'dual-bilateralism' to trilateralism?}

Although its name implies a regional project, NAFTA's original purpose was not to strengthen North American regionalism, or even to encourage regional integration. Rather, the origins of NAFTA are to be found in essentially national calculations: in Canada and Mexico, calculations about their respective bilateral relationships with the US, and in the US, calculations about managing bilateral relations with its two neighbours. While NAFTA may look trilateral, its genesis was not.

Ironically, NAFTA's origins can in part be traced to the rejection in Canada of Reagan's North American Accord, manifested most clearly in the election of the Liberals under Pierre Elliott Trudeau in February 1980. Trudeau embraced a set of overtly economic nationalist policies: the National Energy Program, designed to promote self-sufficiency in energy and insulate Canadian industry from volatility in global energy prices, and a revitalised role for the Foreign Investment Review Agency in promoting indigenous ownership. These initiatives, which had a negative impact on American business interests in Canada, were embraced just as Ronald Reagan was elected and Congress was starting to respond to a steep decline in US trade performance with harsh protectionist measures, causing a major deterioration in Canada-US relations. ${ }^{14}$

This conjuncture posed a serious structural problem for Canadians. After the Second World War, there had been considerable integration between Canada and the US: air defence had been continentalised by the North American Air Defence

13 Robert A. Pastor, 'North America's Second Decade', Foreign Affairs, 83:1 (2004); Pastor, 'Beyond NAFTA: The Emergence and Future of North America', in Yasmeen Abu-Laban, Radha Jhappan and François Rocher (eds), Politics in North America: Redefining Continental Relations (Peterborough: Broadview Press, 2008).

14 Stephen Clarkson, Canada and the Reagan Challenge (Toronto: James Lorimer, 1982); J. L. Granatstein and Robert Bothwell, Pirouette: Pierre Trudeau and Canadian Foreign Policy (Toronto: University of Toronto Press, 1991); Robert Bothwell, Alliance and Illusion: Canada and the World, 1945-1984 (Vancouver: University of British Columbia Press, 2007), chaps. 19-20. 
(NORAD) Command and defence production had been integrated. ${ }^{15}$ The Auto Pact of 1965 continentalised automobile manufacturing. But one result was that Canada's trade dependence on the US had grown to massive proportions by the early 1980s: 72 per cent of imports and 75.8 per cent of exports. ${ }^{16}$ Finding a way to secure access to the American market during a period of Congressional protectionism and White House annoyance became a major policy goal, marginalising and then eclipsing the economic nationalist policies of 1980 . By 1983, the Trudeau government was exploring the possibility of negotiating a series of sectoral free trade agreements with Washington, but within a year Trudeau had retired and the Liberal party had been defeated in the September 1984 elections.

Ironically, Trudeau's economic nationalism helped bring Mulroney to power, since the Conservatives successfully campaigned on a promise to 'refurbish' Canada-US relations. It is true that while in opposition Mulroney had promised never to embrace free trade. However, by 1985 , he had changed his mind, coming to the conclusion that the only way to solve the problem of American protectionism was to pursue a comprehensive free trade agreement. On 1 October 1985, Canada formally requested the opening of free trade talks; an agreement was signed by Mulroney and Reagan on 2 January 1988. Following an election in November 1988 that was largely fought over the agreement, CUSFTA came into force on 1 January 1989.17

CUSFTA represented a radical shift in Canadian politics; in Brian Tomlin's apt phrase, by embracing free trade with the US, Canadians were 'leaving the past behind'. ${ }^{18}$ For indeed 'the past' had weighed heavily since the Liberals under Wilfrid Laurier went down to defeat in the 1911 election on the issue of free trade with the US. That election cast a long shadow, helping to entrench as an axiom of Canadian politics that free trade was tantamount to electoral suicide. ${ }^{19}$ But if the 1988 election results suggested that mass opinion in Canada had shifted, so too had elite opinion changed. Throughout the 19th and 20th centuries, the business community, which thrived on high tariff walls, had generally been strongly opposed to free trade; indeed, business had taken the lead in both 1891 and 1911 elections to oppose the free trade option that was an issue in both those elections. ${ }^{20}$ But by the mid-1970s, faced with a changed economic environment, the business community

15 Joseph T. Jockel, No Boundaries Upstairs: Canada, the United States and the Origins of North American Air Defence, 1945-1958 (Vancouver: University of British Columbia Press, 1987). The Defense Production Sharing Agreements permitted Canadian contractors to bid on US defence procurement and research contracts. On the North American 'zone of peace', see David Haglund, "A Security Community - "If You Can Keep It": Demographic Change and the North American Zone of Peace', Norteamérica, revista académica, 2:1 (2007), pp. 77-100.

16 Granatstein and Bothwell, Pirouette, p. 330.

17 G. Bruce Doern and Brian W. Tomlin, Faith and Fear: The Free Trade Story (Toronto: Stoddart, 1991); Michael Hart, Bill Dymond and Colin Robertson, Decision at Midnight: Inside the Canada-US Free Trade Negotiations (Vancouver: University of British Columbia Press, 1994).

${ }^{18}$ Brian W. Tomlin, 'Leaving the Past Behind: The Free Trade Initiative Assessed', in Nelson Michaud and Kim Richard Nossal (eds), Diplomatic Departures: The Conservative Era in Canadian Foreign Policy, 1984-1993 (Vancouver: University of British Columbia Press), pp. 45-58.

19 Mulroney explicitly dismissed a free trade agreement, saying that that issue had been decided in 1911. Nelson Michaud and Kim Richard Nossal, 'The Conservative Era in Canadian Foreign Policy, 1984-93', in Michaud and Nossal (eds), Diplomatic Departures, p. 9.

20 J. L. Granatstein, Yankee Go Home? Canadians and Anti-Americanism (Toronto: HarperCollins, 1996), pp. 48-9. 
began to shift its view, becoming ardent and vocal advocates for free trade with the US. ${ }^{21}$

But neither elites nor the public in Canada saw the CUSFTA as a harbinger of some larger regional project. On the contrary: the discourse around free trade focused on the nation and its future, with those opposed to the agreement arguing that free trade would see Canada increasingly absorbed into the US, and those favouring free trade arguing that the agreement would increase Canada's wealth and autonomy.

In the US, the agreement was likewise seen in strictly bilateral terms, as a manifestation of the American preference for what Lipsey and Wonnacott call the 'hub-and-spoke' approach to trade. ${ }^{22}$ And while the advantages for American economic interests in embracing comprehensive free trade were recognised, there was no sense that the CUSFTA was the first step towards a trilateral free trade agreement, much less a regional community. Rather, from an American perspective, the agreement was soon seen as a useful template that could be used effectively for a bilateral agreement with Mexico.

For the year after the CUSFTA came into force, Mexico asked the US to negotiate a free trade agreement. Like Canada, Mexico had experienced increasing cross-border economic integration since the 1960 s, mainly in the form of migration, both legal and unauthorised, to the US to fill labour shortages, but also as a result of the success of the 1965 Border Industrialization Program that boosted employment in the maquiladora industries. ${ }^{23}$ Like Canada, Mexico had a high level of dependence on trade with the US: by 1994, 78 per cent of exports were going to and 68 per cent of imports were coming from the US. ${ }^{24}$ But, as Carol Wise notes, following the economic disruptions of the 1970s, both Canada and Mexico 'had begun a gradual process of economic liberalization and macroeconomic restructuring to address the cumulative shortcomings of decades of high protectionism' ${ }^{25}$ In Canada, the process was intensified by the combined impact of recession and increasing American protectionism; in Mexico, it was sparked by the 1982 debt crisis. Mexico embarked on a process of commercial liberalisation. ${ }^{26}$ Like Canada, Mexico needed secure access to the US market to secure its goals. And, like Mulroney, Mexican President Carlos Salinas de Gortari, who had in 1988 declared

21 David Langille, 'The Business Council on National issues and the Canadian State', Studies in Political Economy, 24 (1987), pp. 41-85; Christina Gabriel and Laura Macdonald, 'Of Borders and Business: Canadian Corporate Proposals for North American "Deep Integration" ', Studies in Political Economy, 74 (2004), pp. 82-5.

22 Richard G. Lipsey, Canada and the US-Mexico Free Trade Dance: Wallflower or Partner? (Toronto: C. D. Howe Institute, 1990); Ronald J. Wonnacott, Canada and US-Mexico Free Trade Negotiations (Toronto: C. D. Institute, 1990); Ronald J. Wonnacott, 'Trade and Investment in a Hub-and-Spoke System Versus a Free Trade Area', The World Economy, 19:3 (1996), pp. 237-52.

${ }^{23}$ Khosrow Fatemi (ed.), The Maquiladora Industry: Economic Solution or Problem? (New York: Praeger Publishers, 1990).

${ }^{24}$ Andrew F. Cooper, 'NAFTA and the Politics of Regional Trade', in Brian Hocking and Steven McGuire (eds), Trade Politics: International Domestic and Regional Perspectives (New York: Routledge, 1999), p. 235.

25 Carol Wise, 'Unfulfilled Promise: Economic Convergence under NAFTA', in Isabel Studer and Carol Wise (eds), Requiem or Revival? The Promise of North American Integration (Washington, DC: Brookings Institution, 2007), p. 31.

${ }^{26}$ Manuel Pastor and Carol Wise, 'The Origins and Sustainability of Mexico's Free Trade Policy', International Organization, 48:3 (1994), p. 462. 
that a free trade arrangement would not be in Mexico's interests, ${ }^{27}$ also changed his mind: on 10 August 1990, Mexico formally asked the US to start free trade negotiations.

For the US, the idea of replicating with Mexico the same kind of agreement concluded with Canada had a particular appeal. Not only would comprehensive free trade bring the benefits that economic theory posited, but increasing Mexican wealth could solve a persistent problem in the Mexican-American bilateral relationship: large-scale illegal migration. ${ }^{28}$ The calculation was simple: if Mexicans grew wealthier as a result of free trade, fewer of them would seek to migrate to the US. ${ }^{29}$

The Mexican-American free-trade negotiations concerned Canada, for the successful negotiation of a US-Mexican FTA 'jeopardized Canada's privileged status in terms of its institutionalization of its special relationship with the United States'. ${ }^{30}$ The Canadians asked that the bilateral talks be transformed into a trilateral negotiation. ${ }^{31}$

The way in which the negotiations became trilateralised speaks volumes about the nature of the agreement, and why Pastor would characterise NAFTA as dualbilateralism rather than trilateralism. For, in the end, NAFTA was not truly trilateral; rather it was an agreement between two small economies seeking, with comparable levels of desperation, secure access to an increasingly protectionist American market, and a superpower, which had its own reasons for agreeing to a common agreement with its neighbours. Nor was it a prelude to a deeper regionalism. On the contrary: as Gordon Mace put it succinctly, 'the signatories of NAFTA never intended that this more modest achievement could be transformed into something else'. 32

The lack of interest in region-building among the NAFTA parties stands in striking contrast to the regionalism evident in both Europe and Asia. The regionalist project in Europe, born in the aftermath of the Second World War, was driven by a shared desire to avoid future wars between France and Germany, and to re-establish European power in the world. To be sure, the development of regionalism proceeded in fits and starts, due to the periodic resurgence of nationalist interests and identities. However, a number of internal pressures in the early 1980s led to the re-launch of the European project. In particular, the problem of 'Eurosclerosis', and the need to improve Europe's economic competitiveness in a rapidly globalising economy, generated widespread political support for the establishment of the Single European Market. And the establishment of a common currency and the monetary union was

${ }^{27}$ Maxwell A. Cameron and Brian W. Tomlin, The Making of NAFTA: How the Deal Was Done (Ithaca, NY: Cornell University Press, 2000), p. 59.

${ }^{28}$ See Jeffrey S. Passel, Estimates of the Size and Characteristics of the Undocumented Population (Washington, DC: Pew Hispanic Center, 2005), http://pewhispanic.org/files/reports/44.pdf: the number of Mexicans living in the US grew steadily since 1970, with unauthorized migrants accounting for $80-85$ per cent of the increase. By 1990 , there were approximately 4.2 million Mexican-born residents of the US.

${ }^{29}$ For example, Paul Krugman, 'The Uncomfortable Truth about NAFTA: It's Foreign Policy, Stupid', Foreign Affairs, 72:5 (1993), p. 18.

${ }^{30}$ Cooper, 'NAFTA and the Politics of Regional Trade', p. 236.

${ }^{31}$ Maxwell A. Cameron, 'Canada and Latin America', in Fen Osler Hampson and Christopher J. Maule (eds), Canada Among Nations, 1990-91: After the Cold War (Ottawa: Carleton University Press, 1991), pp. 112-13.

32 Gordon Mace, 'Introduction', in Gordon Mace (ed.), Regionalisn and the State: NAFTA and Foreign Policy Convergence (Burlington, VT: Ashgate, 2007), p. 7. 
driven by another important internal dynamic, namely France's determination to stymie the financial primacy of West Germany and the Bundesbank. ${ }^{33}$ These developments led to the full institutionalisation of regionalism in Western Europe: the removal of domestic barriers to the free movement of capital, goods, services and labour among the member states of the European Union; the establishment of supranational institutions for collective decision-making to support the common market; and a commitment to the development of policies aimed at reducing imbalances and disparities within the region.

None of these drivers for regionalism was evident in North America. NAFTA was not conceived in an environment of deep-seated conflict and hostility, nor did its architects frame it as a 'regionalist' response to the emergence of the external economic pressures (such as the creation of the other regionalist blocs, most notably the EU). Nor has the asymmetry of power relations between Canada and Mexico on the one hand and the US on the other produced a dynamic similar to the one that led to the establishment of the euro, whereby the establishment of a common currency and a monetary union was seen as a way of restraining the dominance of the major economic power in the region.

Regionalism in East Asia presents another contrast to North America. There we have seen strong market-led regionalisation in the form of extensive intra-regional trade and investment flows and the establishment of regional production networks by multinational corporations. This occurred largely in the absence of region-wide institutions to provide a supportive framework for this activity, and there has been very little evidence of the sort of internal 'spillovers' that would generate pressures for greater integration, as theorised by neo-functionalists. By contrast, external pressures have had a catalytic effect on the development of both regional identity and regional institutions. In particular, the East Asian financial crises of 1997-98 contributed to region-building in two important ways. First, the crises contributed to a deepening sense of shared 'East Asian' identity, spurred in large part by ill-feelings towards Anglo-American style capitalism in general and the International Monetary Fund in particular. ${ }^{34}$ The crises also prompted the ten members of the Association of Southeast Asian Nations (ASEAN) to work closely together with China, Japan and South Korea - in the so-called ASEAN Plus Three grouping - to establish a regional mechanism to respond to future crises. ${ }^{35}$ While John Ravenhill, in his contribution to this collection, suggests that regional arrangements in East Asia are primarily symbolic rather than substantial, the important point to note is that there is a strong discourse of regionalism in East Asia that is altogether absent in the North American case.

33 Jonathan Story, 'The Origins, Launching and Consequences of "1992" and the Euro: The Politics of Economic and Monetary Integration in Europe', in Bertrand Fort and Douglas Webber (eds),

Regional Integration in East Asia and Europe: Convergence or Divergence? (London: Routledge, 2006), pp. 87-108.

34 Richard Higgott, 'The Asian Economic Crisis: A Study in the Politics of Resentment', New Political Economy, 3:3 (1998), pp. 333-56.

${ }^{35}$ Richard Stubbs, 'ASEAN Plus Three: Emerging East Asian Regionalism?', Asian Survey, 42:3 (2002), pp. 440-55; Helen E. S. Nesadurai, 'Southeast Asia's New Institutional Architecture for Cooperation in Trade and Finance', in Vinod K. Aggarwal and Min-Gyo Koo (eds), Asia's New Institutional Architecture: Managing Trade, Financial and Security Relations (Berlin: Springer Verlag, 2007), pp. 151-80. 
In the East Asian and European cases, regionalism has been driven by different imperatives, and has taken different institutional forms. But in both cases, governments have demonstrated a willingness to negotiate, adopt and implement common policies to strengthen, support and deepen regionalism as a project - in the case of the EU in terms of concrete outcomes and in the case of East Asia in terms of a strong regionalist discourse and preference for regional institution-building. By contrast, we have seen very little evidence of either practical outcomes that strengthen regionalism nor a regionalist discourse in North America.

\section{Desperately seeking deepening: North America's elite-driven regionalism}

Although NAFTA started life as a free trade agreement - and was expected by its framers to remain nothing more than that - the functionalist dynamic first identified in 1961 by Bela Balassa can be seen in the North American case. Balassa's model of economic integration for Western Europe started with a free trade area, then progressively moved to a customs union, followed by a common market, an economic union that involves some harmonisation of national economic policies, and then finally to complete economic integration that unified monetary, fiscal and social policies. ${ }^{36}$ In keeping with functionalist theory, Belassa argued that each stage would generate pressures that could only be solved by moving to the next stage. Some of those pressures emerged in NAFTA's first decade, resulting in some attempts to push deeper North American integration and move to the next stage.

In Canada, for example, there was a short-lived debate in 1999 over proposals a North American Monetary Union, including a new common currency, dubbed the amero. ${ }^{37}$ The euro had just been introduced in Europe and the Canadian dollar was trading at an all-time low of 68 US cents, and a monetary union was seen as a means of resolving some of the instability and uncertainty associated with exchange rates..$^{38}$

In the US, Robert Pastor was the leading advocate of turning NAFTA into something more than a free trade area. A professor at Emory University who had served as the advisor to a bipartisan commission devoted to educating Americans about NAFTA, Pastor's call for greater regionalism in North America, including an endorsement of the amero, was published in August 2001. ${ }^{39}$

In Mexico, regionalism was championed by the state. When Vicente Fox Quesada, the Partido Acción Nacional (PAN) candidate, won the presidency in 2000, he openly embraced the idea of transforming NAFTA. His '20/20 Vision' called for the creation within twenty years of a customs union, a common external tariff, coordinated monetary policies, and particularly the mobility of labour. ${ }^{40}$ (There was an important connection between Fox and Pastor: Pastor had co-authored a book on Mexico and

${ }^{36}$ Bela Balassa, The Theory of Economic Integration (Homewood, IL: Richard D. Irwin, Inc., 1961).

${ }^{37}$ Herbert G. Grubel, 'The Case for the Amero: The Economics and Politics of a North American Monetary Union', Critical Issues Bulletin, The Fraser Institute, 1999: (http://www.fraserinstitute.org/ COMMERCE.WEB/product_files/amero.pdf).

${ }^{38}$ Eric Helleiner, 'The Strange Politics of Canada's NAMU Debate', Studies in Political Economy, 71/72 (2003/2004), pp. 67-99.

39 Robert A. Pastor, North American Community: Lessons from the Old World for the New (Institute for International Economics, 2001).

${ }^{40}$ Ginger Thompson, 'Mexican Leader Visits US with a Vision to Sell', New York Times, 24 August 2000 . 
the US with Jorge Castañeda Gutman, who served as an adviser to Fox during the 2000 election campaign and who subsequently became Fox's foreign minister.) Although after his inauguration Fox backed away from parts of his 20/20 vision, he nonetheless continued to press for 'deepening' and 'broadening' NAFTA, particularly the inclusion of labour mobility. 41

None of these integrative proposals gained much traction in the short term, however. Neither the Canadian government nor the business community in Canada proved interested in the 1999 proposals for monetary union, and they sank from sight. ${ }^{42}$ Pastor's book, which came out in August 2001, and Fox's campaign for a North American economic community, were both eclipsed by the events of 11 September 2001.

The attacks of 9/11 radically shifted the debate about deepening North American integration. While Fox backed away from regionalism after $9 / 11,43$ key actors in all three countries began to push regionalism as a means of dealing with the economic impacts of 9/11. While the United States did not actually close the border on 11 September, the 'Alert Level One' that was declared demanded lengthy inspections at border crossings. The Canadian border was of particular concern after American newspapers reported that some of the 9/11 hijackers had slipped into the US from Canada and that Canada was a 'haven for terrorists'. ${ }^{44}$

In the days after 9/11 line-ups of trucks stretched for more than 30 kilometres down highways leading into the US, with reported cross-border waits of up to 10-12 hours. These delays caused millions of dollars in losses for companies that had become used to just-in-time supply chains. The automotive sector was hit particularly hard, with some plants remaining closed as a result of parts shortages caused by border delays, and estimated lost production of over 50,000 units industry-wide in the days after $9 / 11.45$

Importantly, the changes at the border were given more permanent bureaucratic expression over the longer term. Robert Bonner, Commissioner of the US Customs Service, noted that after $9 / 11$, 'our priority mission ... changed from the interdiction of illegal drugs and the regulation of trade to a security prevention mission: preventing terrorists and terrorist weapons from entering the US.' ${ }^{46}$ In October 2001, the number of customs and immigration officers along the US-Canadian border tripled. A mammoth bureaucracy, the Department of Homeland Security, was created and given the overarching task of making America impervious to attacks.

41 On his call for a North American economic community: 〈http://fox.presidencia.gob.mx/en/activities/ speeches/?contenido $=926 \&$ pagina $=4\rangle$; on his very public call for a migration agreement: 〈http://www.whitehouse.gov/news/releases/2001/09/20010905-2.html〉. Also George W. Grayson, 'Mexico's Southern Flank: The "Third" US Border', Orbis, 50:1 (2006), pp. 59-60.

42 Emily Gilbert, "The Inevitability of Integration? Neoliberal Discourse and the Proposals for a New North American Economic Space after 9/11', Annals of the Association of American Geographers, 95:1 (2005), p. 205.

43 Rogelio Ramirez De la O, 'Mexico: NAFTA and the Prospects for North American Integration', Commentary, 172 (Toronto: C. D. Howe Institute, November 2002): 〈http://www.cdhowe.org/pdf/ commentary_172.pd $\rangle$.

44 Mark Clayton and Gail Russell Chaddock, 'Terrorists Aided by Leaky US-Canada Line', Christian Science Monitor, 19 September 2001.

45 Terror Attacks Stall Industry,' Ward's AutoWorld, l October 2001: 〈http://wardsautoworld.com/ar/ auto_terror_attacks_stall/ $/$. Sang M. Lee and Marijane E. Hancock, 'Disruption in Supply Chain Due to September 11, 2001', Decision Line (March 2005), pp. 8-11.

46 National Commission on Terrorist Attacks on the United States, 7th public hearing, 26 January 2004: 〈http://www.9-1 lcommission.gov/hearings/hearing7/witness_bonner.htm). 
The Uniting and Strengthening America by Providing Appropriate Tools Required to Intercept and Obstruct Terrorism (USA PATRIOT) Act of 2001 gave the American state hugely expanded powers to regulate and control borders. In short, after 9/11 the US was marked by what Thomas Courchene has called 'a new single-mindedness' in which the demands of homeland security would always prevail: 'if the movement of persons, vehicles, and goods across the border compromises US security, then the border arrangements will be altered in ways that will serve to guarantee homeland security'. ${ }^{47}$ As the American ambassador in Ottawa, Paul Cellucci, reminded Canadians, in the post-9/11 world, 'security trumps trade'. ${ }^{48}$

The trumping of trade in what has been called the 'rebordering' of North America $^{49}$ after $9 / 11$ posed a major threat to business interests. To be sure, the three governments negotiated with each other-in parallel sets of bilateral negotiations - to come up with what was called a 'Smart Border' (a border 'smart' enough to keep legitimate movements of people and goods flowing across the line while interdicting or deterring those wishing to harm the US); the US signed a Smart Border agreement with Canada in December 2001 and a virtually identical agreement with Mexico in March 2002. ${ }^{50}$ But Smart Borders would not be able to deal with what business feared most: that American operations with supply chains outside the country would relocate those chains behind American borders rather than face possible disruptions to just-in-time supply caused by the oppressive hand of a border bureaucracy committed primarily to security prevention.

Not surprisingly, the preferred proposed solutions advanced by academics, think tanks, and business groups fixed on assuaging American concerns about security. In Canada, Michael Hart and William Dymond, two former officials who had been involved in the CUSFTA negotiations, argued that border management after $9 / 11$ was 'inadequate'; their 'new design for new circumstances' involved a 'deepening' of integration via a series of incremental moves that focused on 'shoring up US confidence' in Canada's ability to contribute to American security, the creation of a less bureaucratic border, and the establishment of 'a seamless market governed by a single set of rules'. ${ }^{51}$

Five months later, Wendy Dobson, a professor of management at the University of Toronto and a former associate deputy minister in Canada's Department of Finance, proposed what she called the 'Big Idea' that was needed to capture the attention of an American government transfixed by threats to security. Her 'Big Idea' was not to push for a customs union or common market, but rather a 'strategic

47 Thomas Courchene, 'FTA at 15, NAFTA at 10: A Canadian Perspective on North American Integration', North American Journal of Economics and Finance, 14 (2003), p. 275.

48 Joseph Brean and Sheldon Alberts, 'US Loses Faith in Canada', National Post, 26 March 2003; Paul Cellucci, Unquiet Diplomacy (Toronto: Key Porter Books, 2005); Munroe Eagles,

'Canadian-American Relations in a Turbulent Era', PS: Political Science, 39:4 (2006), pp. 821-4.

49 Thomas J. Biersteker, 'The Rebordering of North America? Implications for Conceptualizing Borders after September 11', in Peter Andreas and Biersteker (eds), The Rebordering of North America: Integration and Exclusion in a New Security Context (New York: Routledge, 2003), pp. 153-66.

50 Rey Koslowski, 'Smart Borders, Virtual Borders or No Borders: Homeland Security Choices for the United States and Canada', Law and Business Review of the Americas, 11:3/4 (2005), pp. 527-51.

51 Michael Hart and William Dymond, 'Common Borders, Shared Destinies: Canada, the United States and Deepening Integration', Policy Debates, Centre for Trade Policy and Law, Carleton University, 20 November 2001: 〈http://www.carleton.ca/ctpl/pdf/papers/cdaus.pdf〉. 
bargain' that would pragmatically try to deal with American security concerns in return for reducing the impediments to trade and the movement of people. Dobson allowed that the process of 'deepening' North American integration would establish 'some customs-union- and common-market-like arrangements', but she argued that this would 'achieve the benefits of a customs union or a common market ... without the harmonization that would undermine political independence'. 52

Gary Clyde Hufbauer and Jeffrey Schott advocated a comparable step-by-step method. They acknowledged that integrative benchmarks such as free migration or legal harmonisation would not be achieved any time soon. 'Rather,' they concluded, 'we take a more pragmatic approach and target the reduction or elimination of specific barriers to the movement of goods, services, capital, and people ... 53

Other contributors to the debate rejected such limited visions. In the US, for example, a Brookings Institution conference in December 2001 featured Perrin Beatty, the president of the Canadian Manufacturers and Exporters, Andrés Rozental, the president of the Consejo Mexicano de Asuntos Internacionales, and Robert Pastor unambiguously pressing the importance of creating a North American community. ${ }^{54}$ Hugh Segal, the president of the Institute for Research on Public Policy, enthusiastically called for a wholesale embrace of an EU-style 'North American Community', including the creation of political institutions such as an elected 'North American Assembly'.5s Allan Gotlieb, a former deputy foreign minister and Canadian ambassador to the United States, may not have endorsed Segal's expansive vision, but he was critical of the limited and ad hoc nature of many of the proposals on offer:

To believe such issues can be addressed by lobbying or intermittent, patchwork arrangements is unrealistic in the extreme. The national interest requires a grand strategy, aimed at creation of a more comprehensive structure, a community of law, under which the free flow of goods and services and people can be guaranteed. Whether in the form of a common market, a customs union, a community of laws inspired by the European model, or some unique hybrid, such an agreement would entail the reduction and eventual abolition of all trade-remedy actions between our two countries, and their replacement, as in Europe, with a common competition policy. ${ }^{56}$

The proposals for deeper integration as a means of resolving the security-trade dilemma were also being pushed in the political arena. For example, in January 2003, Thomas d'Aquino, president of the Canadian Council of Chief Executives (CCCE), a peak organisation of CEOs from approximately 150 corporations, ${ }^{57}$ launched the North American Security and Prosperity Initiative. The CCCE initiative explicitly acknowledged that EU-like common market and supranational institutions would not work in North America; instead, it sought 'action' in five areas. These included:

52 Wendy Dobson, 'Shaping the Future of the North American Economic Space: A Framework for Action', The Border Papers: C. D. Howe Institute Commentary 162 (Toronto: C. D. Howe Institute, April 2002), pp. 29-30: 〈http://www.cdhowe.org/pdf/commentary_162.pdf .

53 Hufbauer and Schott, NAFTA Revisited, pp. 468-9; emphasis in original.

${ }^{54}$ Peter Hakim and Robert E. Litan (eds), The Future of North American Integration: Beyond NAFTA (Washington, DC: Brookings Institution Press, 2002).

55 Hugh Segal, 'North American Community: A Prospect to Excite and Inspire', Inroads: A Journal of Opinion, 13 (2003), 〈http://www.inroadsjournal.ca/archives/inroads13/tocl3.htm).

56 Allan Gotlieb, 'Romanticism and Realism in Canada's Foreign Policy', Benefactors Lecture 2004 (Toronto: C. D. Howe Institute, November 2004), p. 40.

57 Formerly the Business Council on National Issues, which had been active in pressing for a free trade agreement with the United States in the 1980s. 
a 're-invention' of North American borders to create 'a zone of cooperation encompassing the continent' that would allow North America to be 'open to business but closed to terrorism'; the harmonisation of regulatory frameworks; the negotiation of a resource security pact; the creation of a 'North American defence community of sovereign nations'; and the creation of 'specialized joint commissions' to implement these initiatives..$^{58}$ In April 2003, the CCCE formed a 30-person 'Action Group' of CEOs from major corporations to push the integration agenda forward.

This initiative was given added impetus when the Council on Foreign Relations launched a 'task force' in November 2004 to explore how to provide both security and prosperity. The task force was trinational - sponsored by the CFR, the CCCE, and the Consejo Mexicano de Asuntos Internacionales (COMEXI) - and chaired by John Manley, a former deputy prime minister and foreign affairs minister of Canada, Pedro Aspe, a former secretary of the Treasury of Mexico, and William Weld, a former governor of Massachusetts. Not only were the vice-chairs familiar names in the regionalist project - Thomas d'Aquino, Robert Pastor, and Andrés Rozental but a number of task force members had also contributed to the debate. Not surprisingly, the final report reflected many of the ideas that had been circulating since $9 / 11$.

Building a North American Community, published in May 2005, was a 32-page blueprint; although brief, its recommendations were both ambitious and comprehensive. They included the creation of a common security perimeter, the negotiation of common external tariffs on a sector-by-sector basis, and moves to create a common economic zone, including full labour mobility. Some of the recommendations focused on harmonisation, from border management to 'tested once' regimes for pharmaceuticals to trinational recognition of professional standards. Some focused on institution-building: a permanent tribunal for dispute resolution, a trinational competition commission, an institutionalised annual summit meeting of heads of government, a North American Advisory Council, a North American InterParliamentary Group. Specific proposals ranged from the adoption of a North American Border Pass, a North American Investment Fund to encourage investment in Mexico, the signing of a North American resource accord, and the creation of education initiatives comparable to programs in place in the EU. ${ }^{59}$

\section{Responses to deeper integration}

By the time that the CFR Task Force reported, the three governments had already responded with an initiative intended to address the regionalist ideas being bruited by business. Indeed, they even named it after the initiative launched in 2003 by the CCCE: the Security and Prosperity Partnership (SPP). According to Stephen Clarkson, ${ }^{60}$ this initiative had its origins in Washington in 2003, but it was not until Bush visited Canada

${ }^{58}$ Canadian Council of Chief Executives, Security and Prosperity: Toward a New Canada-United States Partnership in North America, January 2003: (http://www.ceocouncil.ca/en/publications/ publications.php).

59 Building a North American Community: Report of an Independent Task Force (New York: Council on Foreign Relations, 2005).

${ }^{60}$ Stephen Clarkson, 'Does North America Exist? Transborder Governance after NAFTA and the Security and Prosperity Partnership', Norteamérica, Revista Académica, 2:2 (2007), p. 99. 
in November 2004 that he and the Canadian prime minister discussed a 'new partnership' for 'enhanced security, greater prosperity and improved quality of life.'61 The initiative was announced by the three leaders at a summit at Waco, Texas, on 23 March 2005.

The SPP created two 'agendas'. The security agenda focused on external and internal threats to North America, as well as finding ways to 'streamline the secure movement of low-risk traffic across our shared borders'. The 'prosperity agenda' sought to enhance productivity, reduce the costs of trade, and improve the quality of life. Ten working groups were charged with advancing the 'prosperity agenda' (unlike the security agenda, which was not organised into working groups). ${ }^{62}$

Although the actual work of the SPP is conducted at the bureaucratic level, the three leaders review the work at an annual meeting, colloquially (and embarrassingly) dubbed the 'Three Amigos' summit. Bush, Fox and the newly-elected Stephen Harper met in Cancún in March 2006; Bush, Harper and the newly-elected Felipe Calderón Hinojosa met in Montebello in August 2007 and in New Orleans in April 2008. In addition, the nine ministers/secretaries of the three countries responsible for 'security' and 'prosperity' - from foreign affairs, commerce/industry/economy, and homeland security/public safety/interior - met prior to the leaders' meeting: in Ottawa in February 2007 and in Los Cabos in February 2008.

The SPP grants business special and privileged access to the three leaders. In March 2006 the corporate community established a trinational North American Competitiveness Council (NACC), a group of 30 companies, ten from each country, with a peak business association in each country serving as a national secretariat. At each summit, the NACC is given an opportunity to report to the leaders on ways to enhance the competitiveness of the North American economies. ${ }^{63}$

While it might appear that there were similarities between the SPP and the various proposals for deeper North American integration discussed above, and while the SPP appears on the surface to be an example of North American regionalism, ${ }^{64}$ it is in fact deeply ironic. Although its name was appropriated from a corporate initiative, it is clear that none of the governments involved in the SPP was keen to advance North American integration in the way that the corporate sector was proposing. Moreover, while Fox was enthusiastic about pressing North American regionalism - unlike Bush, Martin, or Harper - the arrival of Calderón in Los Pinos meant that as of 2007 , all three of the 'amigos' had precisely the same enthusiasm for regionalist projects, which is to say virtually none at all.

On the contrary: the SPP involved a neat sleight of hand: it appeared to create the integrative arrangements that were being pressed by the corporate, academic and think tank communities, and it certainly did create privileged access to the corporate community that was denied to other civil society groups. But in substance, there was little trilateral space created by the SPP; instead dual-bilateralism continued to reign. Indeed, Roland Paris, one of the bureaucrats who worked on the creation of the SPP,

${ }^{61}$ Brian Laghi, Jeff Sallot and Alan Freeman, 'The Lazy Summit', Globe and Mail, 1 December 2004, p. A4.

62 http://www.spp.gov〉.

${ }^{63}$ For example, 〈http://www.uschamber.com/publications/reports/0804_global_challenge.htm〉.

${ }^{64}$ Emily Gilbert, 'Leaky Borders and Solid Citizens: Governing Security, Prosperity and Quality of Life in a North American Partnership', Antipode, 39:1 (2007), p. 81; Clarkson, 'Does North America Exist?', pp. 100-1. 
argued that the initiative turned into a way to organise and mobilise bureaucratic action on a large number of existing policy dossiers on highly technical policy matters. He dismissed the SPP as nothing more than a 'hodgepodge of bilateral and trilateral working groups' that did little more than generate 'grocery lists' that lacked 'any organizing vision or direction'.65 Certainly the highly technical bureaucratic work reported on the official websites ${ }^{66}$ suggests that Paris's biting description of the SPP as consisting largely of 'mind-numbing lists of mostly piddling initiatives' is not unwarranted.

But the second irony of the SPP is that its creation had exactly the opposite political impact than the one intended by its enthusiasts. Recent work by students of regionalism recognises the degree to which regions are 'imagined' or 'socially constructed', and not just economically determined. ${ }^{67}$ As Wendy Larner and William Walters remind us, regions 'are not inevitable expressions of geography, but are "imagined communities" produced by region-building elites', and that therefore we should pay 'greater attention ... to the "inventedness" of regions' ${ }^{68}$ Likewise, recent scholarship on regionalism alerts us to the importance of identity and values in shaping enthusiasm for, or resistance to, regionalist projects. And we can see that the advocacy by the business community of an explicitly regionalist solution for North America, even if it had uniquely North American characteristics, and the apparent endorsement of that project by the three governments of North America by their embrace of the SPP, triggered significant resistance among civil society actors that, we will argue, has actually served to dampen the growth of regionalism in North America since the launch of the SPP.

In all three countries, the SPP was greeted by many critics as heralding a new political project designed to eliminate the existing nation-states of North America and to create a supranational entity comparable to the EU. In Canada and Mexico, the SPP was opposed by mainly by civil society organisations on the left, such as the Council of Canadians, Common Frontiers, Green Party of Canada, Réseau québécois sur l'integration continentale, the Red Mexicana de Acción Frente al Libro Commercio and the Diálogo Nacional por la Defensa de la Soberanía. Joined by some American CSOs, such as the Alliance for Responsible Trade and the Citizens' Trade Campaign, these trinational networks had coalesced around the free trade debates of the early 1990s and the anti-globalisation protests of the late 1990s and early 2000s; after the inauguration of the SPP, these networks mobilised to oppose what they characterised as the undemocratic nature of efforts at greater economic and political integration such as the SPP, focusing on Web activism and street protests. 69

Opposition also came from the right, but was concentrated primarily in the US. The American right fixed on a single concern: that the SPP was the first step in a 'secret' plan by government and corporate 'elites' to merge the US with Canada and

${ }^{65}$ Roland Paris, 'A Trilateral Mishmash', Globe and Mail, 26 February 2007.

${ }^{66}\langle\mathrm{http}: / / \mathrm{www}$. spp.gov/ $/$, 〈http://www.spp-psp.gc.ca/menu-en.aspx, http://www.aspan.gob.mx//.

${ }^{67}$ For example, Franceso Duina, The Social Construction of Free Trade: The European Union, NAFTA, and Mercosur (Princeton, NJ: Princeton University Press, 2006).

68 Wendy Larner and William Walters, "The Political Rationality of "New Regionalism": Towards a Genealogy of the Region', Theory and Society, 31 (2002), p. 393; also Arif Dirlik, What Is In a Rim? Critical Perspectives on the Pacific Region Idea, 2nd edn (Lanham, MD: Rowman and Littlefield, 1998).

69 Ayres and Macdonald, 'Deep Integration and Shallow Governance', pp. 31-2. 
Mexico and create a North American Union. The clearest evidence for this, it was claimed, was the plan to construct a 'NAFTA Superhighway', a giant multi-modal highway system linking Mexico, the US, and Canada. This highway would have ten lanes of car/truck traffic; the median would be used for railways and oil, gas and water pipelines. The main superhighway was going to run from Manzanillo and Lázaro Cárdenas, up through San Antonio and Kansas City, where it would branch northwest to Omaha, Winnipeg and Alberta, and northeast to Chicago, Detroit, Toronto and Montreal. This highway was going to be of enormous proportions: descriptions routinely put it as the width of four football fields - that is, nearly 400 metres/1200 feet wide - thus requiring not only vast expenditures, but vast expropriations of land across the midwestern US. More disturbingly still in the minds of opponents, it was going to be an international highway, where American law would not prevail, meaning that unregulated and unsafe Mexican trucks could come into the US carrying drugs, smuggled humans and terrorists, and crash into unsuspecting Americans who would be powerless to collect insurance. ${ }^{70}$

Opposition to the North American Union and the NAFTA Superhighway was galvanised largely on the Web, particularly through postings to YouTube. Large numbers of conservative organisations were involved in the anti-SPP movement, including national groups like Phyllis Schlafly's Eagle Forum and other civil society organisations on the right, such as the Minutemen and the John Birch Society. The on-line versions of conservative publications, such as The American Conservative, Human Events, and WorldNetDaily were also important in producing-and reproducing - the message. Typically, postings by peak groups or key individuals in the movement were copied verbatim and reposted to a vast number of sites and blogs. ${ }^{71}$ But opposition to both the NAU and the NAFTA Superhighway was also legitimised by mainstream figures as varied as CNN's Lou Dobbs, conservative commentator Patrick Buchanan, presidential candidate Ron Paul, union president James Hoffa, and numerous politicians at both the state and federal level who treated the concerns being expressed seriously. ${ }^{72}$

The irony of the SPP debate in the US is that the robust opposition to the initiative was based on a conspiracy theory. Although the SPP comes nowhere close to creating the conditions for a North American Union, parts of the SPP can easily be (re)constructed to make it appear as though there is a secret plan by the president to ignore the constitution and dismantle the US. Likewise, the NAFTA Superhighway was (and is) entirely mythical. It was based on a literal interpretation of a stylised map of North America posted to the Web by an organisation called NASCO - North America's SuperCorridor Coalition. ${ }^{73}$ NASCO is a coalition of companies such as American Airlines Cargo and Lockheed Martin, entities such as the Ambassador Bridge between Windsor and Detroit, and numerous state, provincial, county and municipal governments in the three countries. Since 1994, its goal has been to encourage the movement of goods more efficiently by greater use of existing

\footnotetext{
${ }^{70}$ See, for example, Jerome Corsi, The Late Great USA: The Coming Merger with Mexico and Canada (New York: WND Books, 2007), pp. 91-116.

71 Googling 'North American Union' yields 1.6 million results.

${ }^{72}$ For example, 〈http://nauinfo.blogspot.com/2008/02/lou-dobbs-nafta-superhighway-21908.html

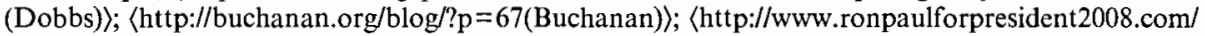

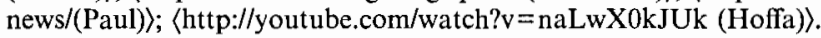

${ }^{73}\langle\mathrm{http} / / / \mathrm{www}$. nascocorridor.com $\rangle$.
} 
multi-modal transportation corridors in the middle of the continent. However, the map originally marketing their idea showed a stylised set of roads and railways that was (purposely) completely out of proportion. ${ }^{74}$ But this map was widely copied to thousands of websites, stirring numerous Americans into political action against this putative threat.

It is a useful reminder of just how unusual American politics is that a conspiracy theory would gain the considerable political traction it did. ${ }^{75}$ The NAU and the NAFTA Superhighway became mainstream issues, to be raised with presidents during press conferences as serious matters (as Bret Baier, FOX News's White House correspondent, did at a press conference in August 200776). Likewise, politicians at both the federal and state levels took the issue seriously enough to register their views, even if only symbolically. But it is indicative that as of April 2008, resolutions expressing opposition to the North American Union and the NAFTA Superhighway had been introduced in the legislatures of almost half the states in the union, and that 44 members of the House of Representatives from twenty-two states had agreed to co-sponsor a concurrent resolution expressing the sense of Congress that 'the United States should not engage in the construction of a North American Free Trade Agreement (NAFTA) Superhighway System' for fear, inter alia; that 'unrestricted' trucking would be 'a conduit for the entry into the United States of illegal drugs, illegal human smuggling, and terrorist activities'. ${ }^{77}$ For its part, the White House felt compelled to post a 'fact sheet' on its SSP website seeking to debunk the myths ${ }^{78}$ (even though for committed conspiracy theorists denial is merely confirmation of the existence of the conspiracy). Finally, we should not ignore the impact of the SPP debate on the electoral campaigns of candidates for the Democratic nomination in 2008: both Hillary Rodham Clinton and Barack Obama did not hesitate to criticise NAFTA during the primaries for its negative impact on manufacturing jobs in the US. 79

The reactions to the Security and Prosperity Partnerships of civil society groups from both the left and the right demonstrate the difficulty of embracing regionalism in a North American context. To be sure, much of the opposition to the SPP reflected a deep concern, particularly in those parts of the US hard hit by the migration of manufacturing, about job losses. But there can be little doubt that Americans, Canadians and Mexicans, when confronted with projects that can be constructed as regionalist, such as NAFTA or the SPP, tend to have a very different reaction than Europeans. As Frank Graves has shown, in Europe we have seen a long secular decline in national attachments, but a secular increase in local identities, and a dramatic rise in European identity. In North America, by contrast, he shows that there has been a decline in local identity and a dramatic increase in national attachment - but that identification with 'North America' continues to be relatively

\footnotetext{
${ }_{75}$ An original version of the map is at $\langle\mathrm{http}: / /$ www.mmlv.us/nacorridors.html〉.

${ }^{75}$ Michael Barkun, A Culture of Conspiracy: Apocalyptic Visions in Contemporary America (Berkeley, CA: University of California Press, 2003).

76 http://www.whitehouse.gov/news/releases/2007/08/20070821-3.html).

77 H.Con.Res. 487, 109th Congress, 2nd session, 28 September 2006; reintroduced in the 110th Congress as H.Con.Res. 40, 22 January 2007. For cosponsors, 〈http://www.govtrack.us/congress' bill.xpd?bill $=\mathrm{hc1} 10-40\rangle$.

${ }^{78}\langle$ http://www.spp.gov/myths_vs_facts.asp $\rangle$.

79 Gordon Trowbridge, 'Clinton, Obama Call for NAFTA Changes', Detroit News, 27 February 2008.
} 
low. ${ }^{80}$ To a consideration of how the particular conditions of North America limit the growth of the regional identity that would be necessary for the growth of regionalism we now turn.

\section{The US and regionalism}

In the previous section, we explained why the governments of Canada, Mexico and the US responded so cautiously to various business proposals for the deepening of the regionalism in North America. In this section, we question whether regionalism that is, state-led efforts to deepen regional integration through the fostering of formal mechanisms to support institutionalised cooperation and collective action - is a viable political option for the US given its structural power and preferences.

Any deepening of economic integration along the lines advocated by the proponents of a North American community would necessarily require the strengthening of regional institutions to provide a framework for deepened cooperation in policy and governance. But, given the nature of US structural power in the regional and global economy, to what extent would it be willing to participate in joint decision-making processes through strengthened regional institutions? There are several ways of answering that question.

First, we have observed that NAFTA is better understood as 'dual bilateralism' between the US and two 'spokes' rather than as a trilateral or regional agreement. At no time has any US administration demonstrated any interest in pursuing deeper forms of North American regional integration that would vest any significant policy-making authority in an intergovernmental institution, much less a supranational one. This was very much evident in the deliberate weakness of the institutions that are meant to support NAFTA. The NAFTA Secretariat does not exist as a sole authority but is constituted by three national Sections offices, which are 'mirror images' of each other. ${ }^{81}$ There is also a Commission for Labor Cooperation and a Commission for Environmental Cooperation. However, these were designed to ensure the least disruption to national policies and governance; like the NAFTA Secretariat itself, they have minimal mandates, meagre funding and little influence. ${ }^{82}$ In that sense, they reflect the strong US preference to maintain its policy autonomy, not just in the conduct of its foreign economic relations but also in the conduct of its domestic economic policies.

To be sure, no serious advocate of deepening North American integration advocates an EU-style approach that involves the establishment of supranational institutions and the pooling of sovereignty, for such a proposal would be anathema

${ }^{80}$ For survey results on the identification of Americans, Canadians, and Mexicans as 'North American,' see Frank Graves, 'North America: Mosaic, Community, or Fortress?' Norteamérica, Revista Académica, 2:2 (2007), figs. 1-3, pp. 107-8; Centro de Investigación y Docencia Económicas, Mexico and the World 2006: Leaders, Public Opinion and Foreign Policy in Mexico, the United States, and Asia: A Comparative Study (Mexico, 2006), p. 26; Robert Pastor 'The Future of North America', Foreign Affairs, 87:4 (July/Aug 2008), p. 92.

81 The NAFTA secretariat website is $\langle$ http://www.nafta-sec-alena.org/DefaultSite/index.html $\rangle$.

82 Hufbauer and Schott: NAFTA Revisited, $\mathrm{p} 62$. 
to all three NAFTA governments. ${ }^{83}$ But even if the Canadian and Mexican governments were to arrive at the view that it was desirable to establish robust regional institutions for collective decision-making, it is difficult to imagine the US being receptive to any institutional or inter-governmental arrangement where its authority and interests did not predominate. For as Isabel Studer notes, the most significant political impediments to deepening regionalism in North America 'exist in the United States, where deeply engrained biases against the creation of supranational institutions prevail, particularly in Congress. ${ }^{94}$

Indeed, the history of US involvement in multilateral institutions suggests that the US jealously guards its national sovereignty and unless it can dominate the decision-making processes of such intergovernmental institutions, it is generally reluctant to participate in them or to have its freedom of action in any way restrained. This is not a recent development or reflective of the unilateralism of the George W. Bush era. For instance, sovereignty concerns were central to the decision of the administration of Harry S. Truman not to submit the Charter of the International Trade Organization to the Senate in 1950, whereas the predominance of US power in the other Bretton Woods institutions - the International Monetary Fund and the International Bank for Reconstruction and Development - meant that these passed without controversy. Likewise, even during the heyday of multilateralism, some uncontroversial treaties that were supported by the White House were not ratified by Congress due to concerns about their impact on US sovereignty (for example, the 1979 Convention on the Elimination of All Forms of Discrimination Against Women, the 1982 United Nations Convention on the Law of the Sea, and the 1992 Convention on Biological Diversity).

In short, Congressional politics reflects and reproduces the concerns expressed by CSOs and state legislators about the threat - real and imagined - to US sovereignty posed by proposals for the deepening of regional integration in North America. In that sense, opposition to the 'regional project' is not just about reluctant civil societies; more importantly, it reflects a much longer trajectory of US political preferences and the reluctance of the hegemon to be bound by intergovernmental agreements where its interests did not predominate, or where its sovereignty was in any way eroded. As Andrew. Hurrell notes, 'The explicit preference of the United States has been to avoid any institutional framework that would allow for the internal development of integration and that might constrain its legal and political autonomy ... ${ }^{85}$ Indeed, the US - like other great powers - shows very few tendencies towards becoming a 'post-sovereign' polity. After $9 / 11$, the heavy re-borderisation of America and the re-assertion of the national security state demonstrate the degree to which the US - and vast numbers of Americans - remain deeply attached to the Westphalian paradigm.

The implications for regionalism in North America are obvious. US structural power, together with its sovereignty concerns, will mean that regional decisionmaking in important policy domains is unlikely to be joint, consensual and

${ }^{83}$ The exception is Jerry M. Rosenberg, The New American Community: A Response to the European and Asian Economic Challenge (New York, Praeger, 1992).

${ }^{84}$ Isabel Studer, 'Obstacles to Integration: NAFTA's Institutional Weakness', in Wise and Studer (eds), Requiem or Revival?, p. 71.

85 Andrew Hurrell, 'Hegemony in a Region that Dares not Speak its Name', International Journal, 61:3 (Summer 2006), p 563. 
binding. As Stephen Clarkson has observed, to the extent that North America has been 'regionalised', it is via policy coordination conducted by a hegemonic power. ${ }^{86}$ Moreover, attempts to deepen integration in key areas such as the establishment of a common currency would see Canada and Mexico cede significant control to the US, which 'would insist on calling the shots' on monetary policy. ${ }^{87}$ In that sense, if regionalism is going to deepen in North America, it will be what Christian Deblock calls 'régionalisme à l'Américaine' 88 - a harmonisation by Canada and Mexico of their policies with those of the US - that is, the deepening of the hub-and-spokes model that NAFTA continues to be.

\section{Conclusion}

There can be little doubt that NAFTA has deepened the process of economic regionalisation in North America. In turn, this has generated strong interest among business elites for the deepening of regionalism through the creation of a North American community - the so-called 'big idea'. Supported by robust regional institutions, the 'community' would establish for Canada, Mexico and the US a common security perimeter, a common external tariff, and a common economic zone that enabled full labour mobility. As such, these proposals would significantly deepen the fairly shallow integration that has been achieved through NAFTA.

The arguments presented in this paper would suggest that such proposals are doomed to fail, and that elite-driven efforts to deepen regionalism have, in fact, produced a contradictory response. This can be attributed in part to NAFTA's origins as a 'dual bilateral' arrangement, rather than as a 'trinational', 'continental', or 'regional' agreement. Dual bilateralism continues to be the key dynamic in the relationships between the three NAFTA members; one of the most vigorous proponents of the idea of a North American community, Thomas d'Aquino, admitted as much in a 2008 speech that focused on the role of Canada-US cooperation in advancing North American integration. In d'Aquino's words:

My reason for focusing on the bilateral is because a significant number of the more far-reaching proposals I have discussed in the context of the new big idea cannot be implemented trilaterally - at least not in the near term ... What we must not do, however, is to allow the trilateral paradigm with some of its all too apparent constraints to hold back the natural and logical evolution of Canada-United States relations. A sensible way to make bilateralism and trilateralism work in tandem is to apply the principle embraced within the Security and Prosperity Partnership of 'three can talk and two can $d 0^{\prime}{ }^{89}$

86 Clarkson, 'Does North America Exist?'

87 Hufbauer and Schott, Nafta Revisited, p. 484.

88 Christian Deblock, 'Le nouveau régionalisme, une construction américaine. Le cas de l'investissement', in Claude Serfati (ed.), Mondialisation et déséquilibres Nord-Sud (Brussels: Peter Lang, 2006), pp. 77-106: (http://www.er.uqam.ca/nobel/ieim/IMG/pdf/RegSerfatiGRIC-2.pdf). See also John N. McDougall, 'The Long-Run Determinants of Deep/Political Canada-US Integration', in Thomas J. Courchene, Donald J. Savoie and Daniel Schwanen (eds), The Arts of the State II: Thinking North America (Montreal: Institute for Research on Public Policy, 2004).

89 Thomas d'Aquino, 'Reaching for the Top: Strategic Imperatives for Canada in a Transforming Global Economy', The Simon Reisman Honorary Lecture, Ottawa, 27 March 2008. Emphasis in original. 
Certainly there is not much 'doing' occurring on the part of governments to advance regionalism in North America, as evident in the superficiality of the SPP initiative. Moreover, as we have argued, the response by civil society actors in all three countries to proposals to deepen regionalism has been one of suspicion, resistance and downright hostility, invoking, in turn, political responses that denigrate the regionalism project.

To be sure, the processes of regionalisation will continue to push efforts by the NAFTA members to address issues of common concern, especially in matters of economic and commercial policy. But as we have observed, there are significant political, social and structural dynamics at work which are certain to impede the emergence of North American regionalism, making the prospects for the development of a North American community as dim today as they were when Reagan first bruited the idea of a North American Accord in 1979. 


\section{University Library}

\section{- M M I E E R VA A gateway to Melbourne's research publications}

Minerva Access is the Institutional Repository of The University of Melbourne

Author/s:

Capling, A;Nossal, KR

Title:

The contradictions of regionalism in North America

Date:

2009-02-01

Citation:

Capling, A. \& Nossal, K. R. (2009). The contradictions of regionalism in North America.

Globalising the Regional, Regionalising the Global, (1), 35, pp.147-167. CAMBRIDGE UNIV PRESS.

Persistent Link:

http://hdl.handle.net/11343/32438 